\title{
Determination and Analysis of Hot Spot Areas of Deforestation Using Remote Sensing and Geographic Information System Techniques. Case Study: State Sinaloa, México
}

\author{
Sergio Alberto Monjardin Armenta ${ }^{*}$, Carlos Eduardo Pacheco Angulo², \\ Wenseslao Plata Rocha1, Gabriela Corrales Barraza1, Rosendo Romero Andrade1, \\ Jose Carlos Beltran Gonzalez ${ }^{1}$ \\ ${ }^{1}$ Faculty of Earth Sciences and Space, The Autonomous University of Sinaloa, Culiacan, México \\ ${ }^{2}$ Faculty of Forestry and Environmental Sciences, University of the Andes, Merida, Venezuela \\ Email: "sa.monjardin12@info.uas.edu.mx
}

Received 9 January 2016; accepted 17 July 2016; published 20 July 2016

Copyright (C) 2016 by authors and Scientific Research Publishing Inc.

This work is licensed under the Creative Commons Attribution International License (CC BY).

http://creativecommons.org/licenses/by/4.0/

(c) (i) Open Access

\section{Abstract}

The main objective of this research is to analyze deforestation in State Sinaloa during the period 1990-2014. For this, "deforestationhot-spot areas" were identified, by crossing maps of 1993 and 2011 at a 1:250,000 scale with knowledge from environmental and forest experts from each region. Landsat images from 1990 and 2014 and Terra Amazon System were used to monitor the most critical hot spot area, applying Linear Spectral Mixture Analysis and Image Segmentation Ground Product. In order to generate the map deforestation year zero (1990), every segmented object of ground product was visually assigned to "Forest" and "No-Forest" categories. Therefore, gains and losses were interpreted for the map deforestation year one (2014). Those products were validated with the help of experts on the subject and applying a confusion matrix. Results obtained indicated that the highest forest loss was located in North-Central Sinaloa (hot spot area number two) by establishing the average annual rate of deforestation of $4741.90 \mathrm{ha} / \mathrm{year}$ with an average rate of $0.60 \%$, being higher than the national average rate $(0.37 \%)$. This result affects directlyon calculation of carbonfluxes at nationallevel.

\section{Keywords}

Deforestation, Hot Spot, GIS, Landsat, Terra Amazon

\footnotetext{
*Corresponding author.
}

How to cite this paper: Armenta, S. A. M., Angulo, C. E. P., Rocha, W. P., Barraza, G. C., Andrade, R. R., \& Gonzalez, J. C. B. (2016). Determination and Analysis of Hot Spot Areas of Deforestation Using Remote Sensing and Geographic Information System Techniques. Case Study: State Sinaloa, México. Open Journal of Forestry, 6, 295-304. 


\section{Introduction}

Nowadays, climate change is one of the phenomena that produce lots of environmental and weather problems at different scales, spatial and temporal (Arguelles, Benavides, \& Junguera, 2006), due to natural and anthropogenic causes (United Nations, 1992). It can be stated that the Greenhouse Gases (GHG) are one of the factors that cause changes in the main elements of forming climate (Viola, Paiva, \& Savi, 2010), generated an increase of the content of Carbon Dioxide $\left(\mathrm{CO}_{2}\right)$ in the atmosphere and consequently indicates an increase in the average temperature at the Earth surface.

It has been estimated that $70 \%$ of climate change is caused by burning fossil fuels, changes of the land uses and deforestation (IPCC, 2007). Being the last one, the result of direct conversion from forest land to non-forest by men (United Nations, 1992) generates up to $20 \%$ of GHG emissions in the world, in particular $\mathrm{CO}_{2}$ (IPCC, 2007; Houghton, 2012; Kanninen, Brockhaus, Murdiyarso, \& Nabuurs, 2010; Denman \& Guy, 2007). This process is especially produced by agriculture (Rudel, DeFries, Asner, \& Laurance, 2009) and the growth of urban population (Pacheco, Aguado, \& Mollicone, 2011). One of the latest global assessments conducted by the Global Forest Resources Assessment (FRA) indicates a 76,000 $\mathrm{km}^{2} /$ year loss of forests and a gain of 43,000 $\mathrm{km}^{2} /$ year, equivalent to an annual net loss of 33,000 km$/$ year worldwide in the period 2010-2015 (FRA, 2015). For this reason, it is essential to make accurate estimates of deforestation and forest degradation in order to have information that allows to implement strategies to reduce $\mathrm{CO}_{2}$ emissions. These estimates must be based on information that is available globally, as satellite images, which integrating with field data can determine the loss of forest cover and the estimation of $\mathrm{CO}_{2}$ emissions (Ramankutty et al., 2006).

Nowadays, there are two methods widely used to assess deforestation through techniques developed in the Remote Sensing field (GOFC-GOLD, 2013): analysis by sampling (FAO, 2010; Bartalev, Kissiyar, Achard, Bartalev, \& Simonetti, 2014; Pacheco, 2014; Achard et al., 2006) and analysis of the entire area to assess (named wall-to-wall) (INPE, 2013; Hansen et al., 2013; FSI, 2013). According to Hansen et al. (2013) and the FAO (2010), the highest rates of deforestation were reported in Mexico during the last decade, placed the country in the fifteenth and seventeenth position worldwide, with losses of forests 198,850 ha/year and 195.000 ha/year, respectively. In this regard, the $38 \%$ of deforestation focuses specifically on the northeast and northwest regions (Céspedes \& Moreno, 2010; Pineda, 2010). The state of Sinaloa is located in the northwest region. In 1976, this state presented $55.97 \%$ coverage of forests; by 2006 , it decreased to $49.54 \%$, that was $368,056.25$ hectares of lost (Corrales, 2013).

Given this critical situation, with respect to deforestation of the study area and to have such different results from different researches as background, it is necessary to study more precisely using innovative remote sensing techniques that allow to obtain real values of deforestation in the state of Sinaloa. Deforestation is one of the factors that have the greatest impact on climate change, and at the same time produces various natural effects, environmental, social and economic.

\section{Materials and Methods}

\subsection{Study Area}

The state of Sinaloa is located in the northwest of the country, between North latitudes $27^{\circ} 02^{\prime}$ and $22^{\circ} 29^{\prime}$, and West longitudes $105^{\circ} 24^{\prime}$ and $109^{\circ} 27^{\prime}$ (Figure 1). It is an area of $57,365 \mathrm{~km}^{2}$ and represents $2.9 \%$ of the whole country. The Estate has a $37,000 \mathrm{~km}^{2}$ of forest area of which $7440 \mathrm{~km}^{2}$ correspond to temperate forests; 19,000 $\mathrm{km}^{2}$, high, medium and low jungles; $2120 \mathrm{~km}^{2}$ of arid vegetation composed mainly of bushes and shrubs; and $1520 \mathrm{~km}^{2}$ of hydrophilic and halophytic vegetation (INEGI, 2013). About the implications, particularly the loss of forests and jungles is necessary to evaluate and quantify, due that deforestation causes indirectly drawback in main socio-economic activities, through environmental problems, such as high and low temperatures, droughts, floods, and other complications that directly impact main economic activities like agriculture, livestock, fisheries and tourism.

\subsection{Materials}

For this work, maps of Land Use and Vegetation (LUV) the state of Sinaloa from 1993 and 2011 at a scale 1:250,000 were used, and images from 1990 and 2014 of the multispectral sensor Thematic Mapper (TM) of Landsat 4 and 5 and Operational Land Imager (OLI) of Landsat 8 with 30 m spatial resolution, corresponding to 


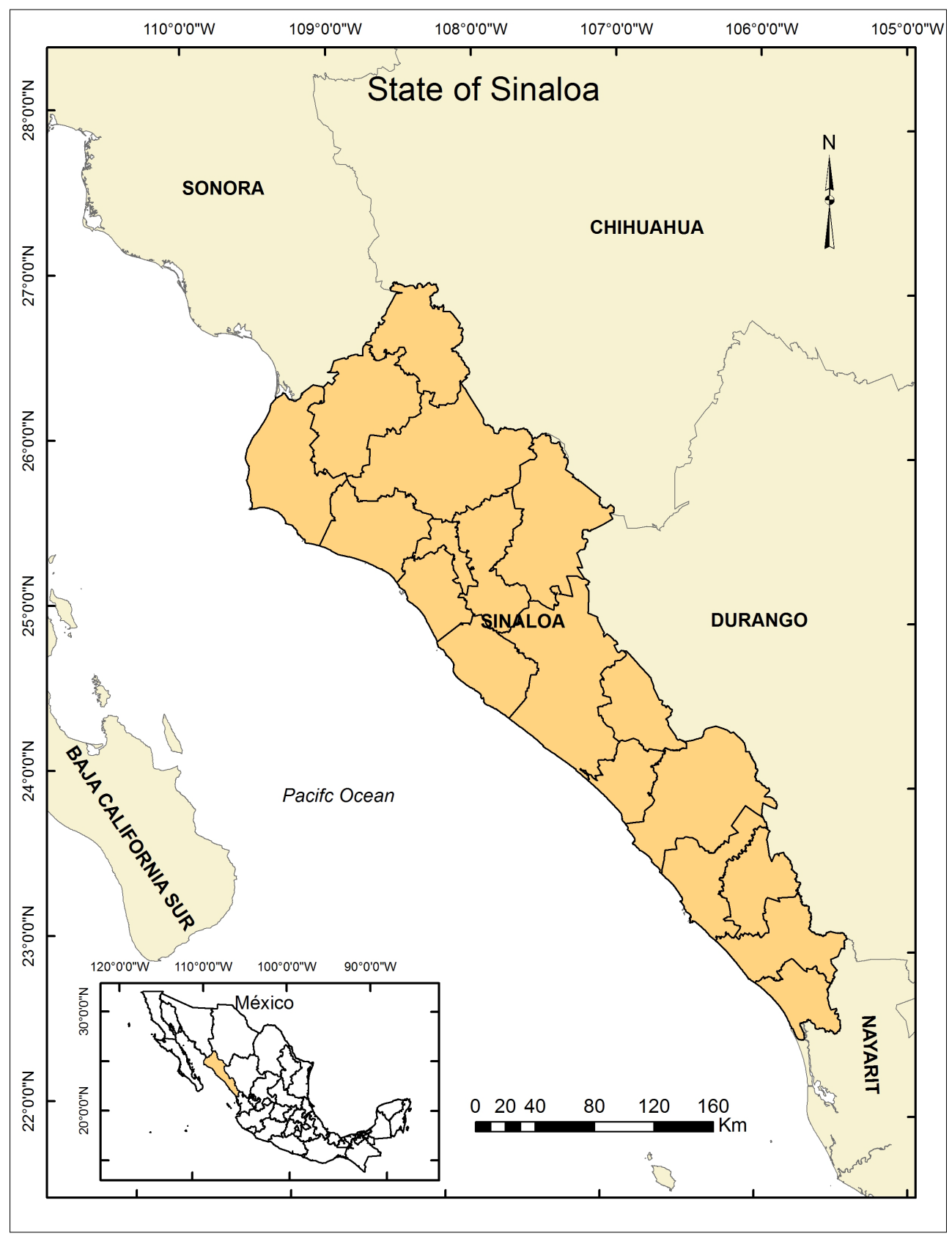

Figure 1. Study area.

the path/row: 033/042, 032/043 and 032/42. Images were obtained from the collection of the Institute of Geological Survey (USGS, 2016), which have a level of radiometric and geometric correction L1T, sufficient for this study.

Remote sensing and geographic information system tools (Spring, Terra Amazon, ENVI and ArcGIS) were used to process the cartographic data.

\subsection{Cartographic Criteria}

- Forest: According to the Mexican Committee for Projects to Reduce Greenhouse Emissions and Capture (COMEGEI) in the Framework Convention of the United Nations Climate Change (United Nations, 1992), Mexico considers forest to a minimum area of land in one hectare with a canopy cover exceeding $30 \%$ and 
minimum tree height of four meters at maturity. For this study, the jungles are considered forest.

- Deforestation: According to the Decision 11/CP.7 of the United Nations (1992) is the direct conversion, induced by man of forested land to non-forest land.

- Base line: To measure deforestation, 1990 is considered the map deforestation year zero; 2014 is year one.

- Legend: For 1990, the categories established were "forest", "non-forest"; 2014, also it was considered "deforestation" and "gains", that represent the loss and recovery of forest cover for the period evaluated.

- Coordinate system: UTM map projection, Datum WGS84.

- Low interpretation Unit (LIU): It was assumed 1.44 hectares.

\subsection{Methodology}

\subsubsection{Identification and Delineation of Hot Spot Deforestation Areas in State Sinaloa}

To generate the cartography of hot spot areas, the maps of Land Use and Vegetation of the years 1993 and 2011 were used; they were produced by the National Institute of Statistics and Geography (INEGI, 2013). The legend of these maps was established as "forest" and "non-forest". To detect the hot spot in areas of deforestation was applied the difference in the maps, a change detection technique that allow us to obtain gains and losses of forest in the period considered, and using expert opinion to delineated this areas (Pacheco, 2014). Based in the cartography mentioned above, the help of external experts and maps of the territorial administrative division were visually identified and delineated four hot spot areas of deforestation in the state of Sinaloa.

\subsubsection{Development of Cartography the Year Zero (1990) and Year One (2014)}

To elaborate the cartography of year zero (1990) and year one (2014) for the most critical hot spot area, the Monitoring System of Deforestation in the Amazon (Terra Amazon) was used, developed by the National Institute for Space Research (INPE) from Brazil (INPE-FUNCATE, 2011).

In order to use this system, it was necessary to configure the system: create a Postgres SQL (Structured Query Language) database, the conceptual model, access control, phase control, project, control rules, the class definition, the definition of control rules and the definition of the area of interest (INPE-FUNCATE, 2011). To interpret and edit the zero year, a composition with false color RGB 453 was created and a technique of Linear Spectral Mixture Model was applied (Shimabukuro \& Smith, 1991), which estimates the proportion of components in soil, vegetation and shade for each pixel from the spectral response of Landsat bands resulting images from the fragment soil, vegetation and shade (or water), using Equation (1):

$$
r_{i}=a * \text { vege }_{i}+b * \text { suelo }_{i}+c * \text { sombra }_{1}+e_{i}
$$

where $r_{i}$ is the response of the pixel in the $b$ and $i ; a, b$, and $c$ are the proportions of vegetation, ground and shade (or water), respectively; vege , suelo $_{i}$ y sombra ${ }_{i}$ are the spectral responses of the components of vegetation, ground and shade (or water), respectively; and $e_{i}$ is the error in the band $i$.

After the fragment soil image was segmented due it provides better contrast between bare soil and forest. To do this, the values of the PRODES Project were used (Bins, Fonseca, Erthal, \& Li, 1993; Câmara, Valerian, \& Soares, 2006). The result of this segmentation was used for a visual interpretation process, which consists of assigning each object segmented to each category "forest" and "non-forest", using the composition with false color 453 RGB as background. Once is generated the cartography of year zero, we proceed to determine the deforestation in year one. Based on the vectors "forest" in year zero, we proceeded to visually interpret deforestation images from year one. The gain is performed based on the vector of "non-forest". This manner, the cartography of year one was obtained with the categories "forest", "non-forest", "deforestation" and "gains".

\subsubsection{Validation of the Maps Year Zero (1990) and Year One (2014)}

After the cartography of 1990 (year zero) and 2014 (year one) were generated the most critical hot spot area, were validated to give strength the products generated and assess the degree of validation. For this, was applied a stratified random sampling in each map of one hundred points for each category. This allowed us to estimate the error contained in the results more accurately and in the shortest possible time (Chuvieco, 2008). The validation was conducted by two experts on the subject and external to the investigation (Congalton \& Green, 2009). With these samples ground-truth, accuracy of each map was quantified by calculating the confusion matrix, from which the errors of omission, commission, overall accuracy and statistical $\mathrm{K}$ were obtained (Congalton \& 
Green 2009; Chuvieco, 2008).

\section{Results}

The change detection analysis made from the maps of 1993 and 2011 of the INEGI, indicated a loss of forest cover of $2277.17 \mathrm{~km}^{2}$, or $3.97 \%$ of the territory of Sinaloa.

From these results, we identified and delineated visually four hot spot areas of deforestation that include partially or totally fourteen of the eighteen municipalities in the state (Figure 2).

As can be seen form this Figure 2, the hot spot area number two is the one with the greatest loss during the period of study (Table 1). For this reason, the methodology of INPE (2013) was applied in order to prove their viability in our region.

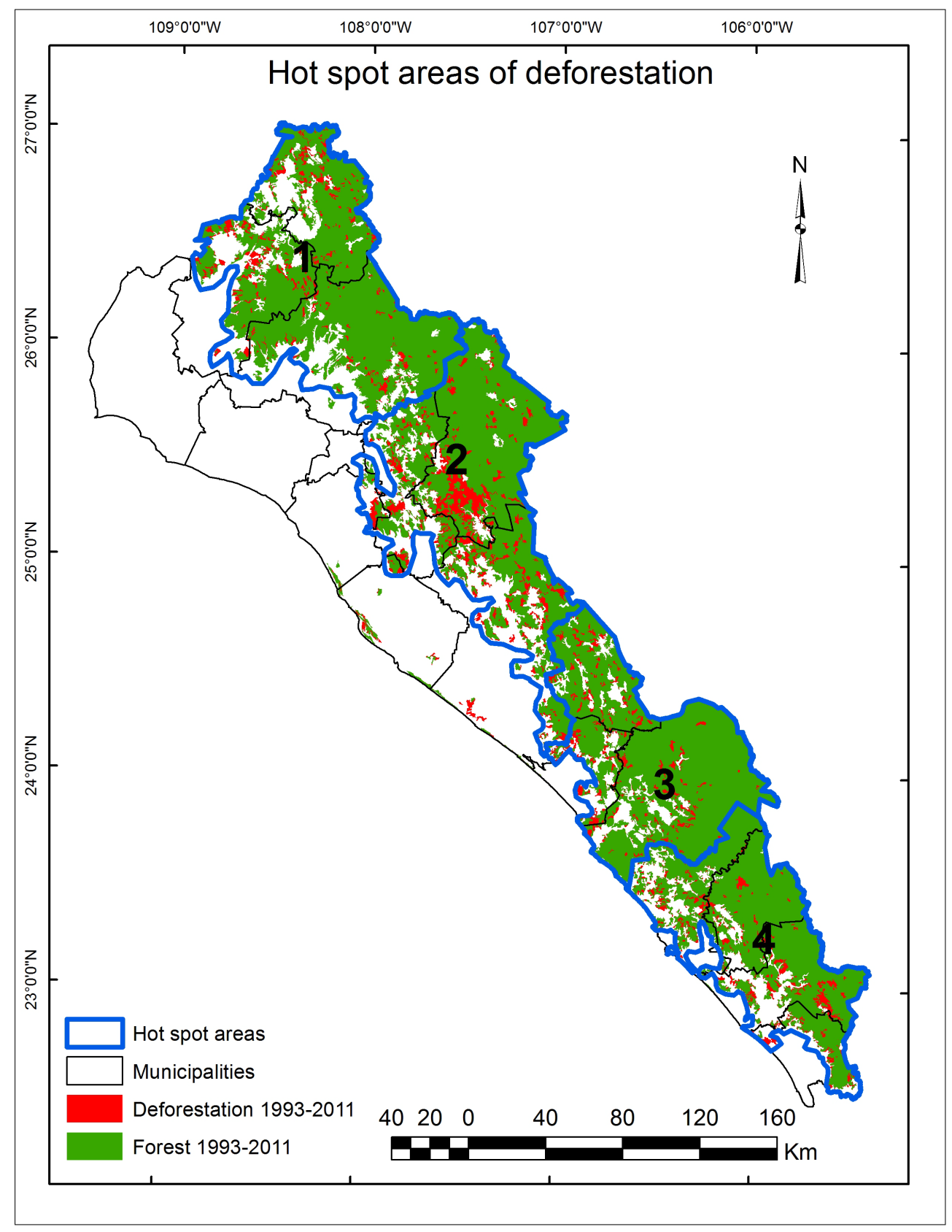

Figure 2. Map of hot spot areas of deforestation in the state of Sinaloa. 
The map results obtained by digital image processing for Year Zero (1990) and Year One (2014) are shown in Figure 3. These maps were obtained with an overall accuracy between $85 \%$ and $88 \%$ (Table 2); while commission and omission errors ranged from $12 \%$ and $15.46 \%$ (Table 3 ). These values obtained are within the set limits $(80 \%$ and $95 \%)$ by scientists to distinguish these classes and then evaluate their changes (GOFC-GOLD, 2013). Meanwhile, the results of kappa for each map were 0.71 and 0.74 respectively. They are acceptable, since their values are in the range 0.61 to 0.80 (Landis \& Koch, 1977).

Once the maps were collected and validated, it was possible to determine that the hot spot area number two had a forest surface of 789,805.43 ha in 1990 and dropped to 675,999.88 ha in 2014. During that period, it was observed that there was a gain of forest in this hot spot area of 5505.08 ha $(0.49 \%)$. However, the loss was considerably higher, with an area of $119,299.54$ ha $(10.72 \%)$, representing an average annual deforestation rate of $0.60 \%$.

\section{Discussion}

Detecting changes by maps of Land Use and Vegetation at 250,000 scale, indicates a loss in the whole state Sinaloa of $2277.17 \mathrm{~km}^{2}$, and from it were identified and outlined four hot spot areas of deforestation, of which the hot spot area number two was presented greater loss of forest cover with a loss of $57.021 \mathrm{~km}^{2} /$ year with an average annual rate of 0.71 , this area includes the municipalities of Culiacan, Badiraguato, Mocorito and Salvador Alvarado.

Table 1. Forest cover during the period 1993-2011.

\begin{tabular}{|c|c|c|c|c|c|c|}
\hline Hot spot area & Municipalities & Surface $\left(\mathrm{km}^{2}\right)$ & $\begin{array}{l}\text { Forest } 1993 \\
\qquad\left(\mathrm{~km}^{2}\right)\end{array}$ & $\begin{array}{l}\text { Forest } 2011 \\
\qquad\left(\mathrm{~km}^{2}\right)\end{array}$ & Loss $\left(\mathrm{km}^{2}\right)$ & $\begin{array}{c}\text { Average annual } \\
\text { deforestation rate }(\%)\end{array}$ \\
\hline 1 & $\begin{array}{c}\text { Choix } \\
\text { El Fuerte } \\
\text { Sinaloa de Leyva }\end{array}$ & $11,399.81$ & 8491.03 & 8118.46 & 372.57 & 0.24 \\
\hline 2 & $\begin{array}{c}\text { Culiacán } \\
\text { Badiraguato } \\
\text { Mocorito } \\
\text { Salvador Alvarado }\end{array}$ & $11,127.77$ & 8457.71 & 7374.31 & 1083.40 & 0.71 \\
\hline 3 & $\begin{array}{l}\text { Cruz de Elota } \\
\text { Cósala } \\
\text { San Ignacio }\end{array}$ & 8385.03 & 7259.19 & 6797.69 & 461.50 & 0.35 \\
\hline 4 & $\begin{array}{l}\text { El Rosario } \\
\text { Concordia } \\
\text { Escuinapa } \\
\text { Mazatlán }\end{array}$ & 7787.62 & 5955.42 & 5568.89 & 386.53 & 0.36 \\
\hline
\end{tabular}

Table 2. Confusion matrices of maps for year zero (1990) and year one (2014).

\begin{tabular}{|c|c|c|c|c|c|c|c|}
\hline \multicolumn{4}{|c|}{ Ground-Truth \% year 0 (1990) } & \multicolumn{4}{|c|}{ Ground-Truth \% year 1 (2014) } \\
\hline & Forest & Non-Forest & Total & & Forest & Non-Forest & Total \\
\hline Forest & 86.32 & 14.85 & 49.49 & Forest & 88 & 14 & 51 \\
\hline Non-Forest & 13.68 & 85.15 & 50.51 & Non-Forest & 12 & 86 & 49 \\
\hline Total & 100 & 100 & 100 & Total & 100 & 100 & 100 \\
\hline
\end{tabular}

Table 3. Errors of commission and omission of maps for year zero (1990) and year one (2014).

\begin{tabular}{cccccc} 
& Errors (\%) year 0 (1990) & & & \multicolumn{2}{c}{ Errors (\%) year 1 (2014) } \\
\cline { 2 - 2 } Class & Commission & Omission & & Class & Commission \\
Forest & 15.46 & 13.68 & Forest & 13.73 & Omission \\
Non-Forest & 13.13 & 14.85 & & Non-Forest & 12.24 \\
\hline
\end{tabular}




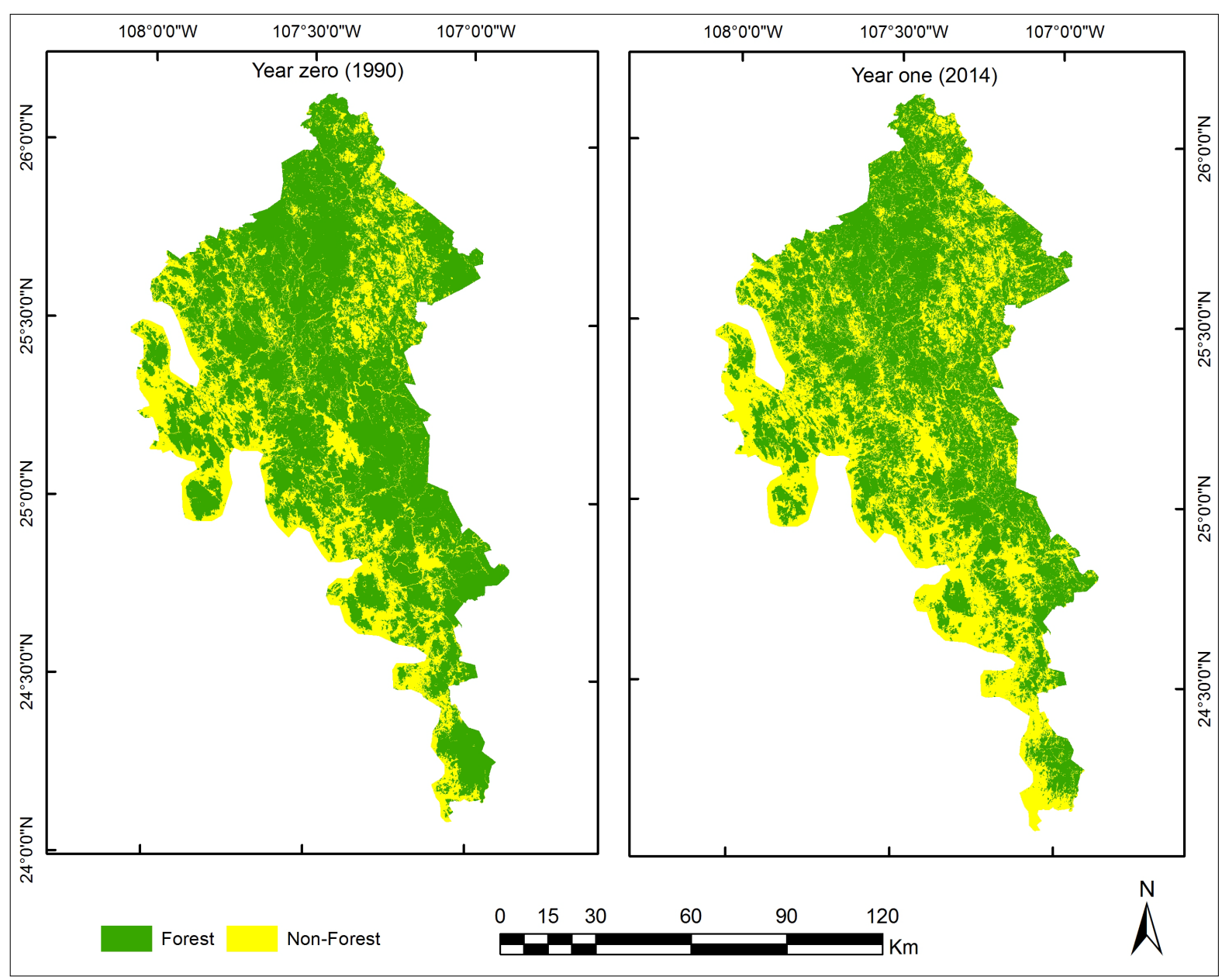

Figure 3. Maps of the forest cover zero (1990) and one (2014).

On the other hand, through the digital processing of Landsat images the hot spot area number two indicates a losing of forest coverage of $47.419 \mathrm{~km}^{2} /$ year with an average annual rate of 0.60 .

Therefore, there is an overestimation of deforestation when maps at 1:250,000 scale is used as shown in Figure 4 and shown in Table 4.

In this regard, in Mexico there have been several studies about deforestation (Mas et al. 2004; StéphaneCouturier et al. 2012; Velázquez et al. 2008; Skutscha et al. 2013; Torres et al. 2008), and particularly in Sinaloa (Corrales, 2013), which used the maps of Land Use and Vegetation at 250,000 scale, thus they could overestimate or underestimate deforestation. For this reason it is feasible to perform this methodology to assessment deforestation at the local, regional and national level.

\section{Conclusion}

The assessment of forest cover showed high rates of deforestation that was constantly presented in the state of Sinaloa during the period 1990-2014. Annual average rates for our study area are higher than those presented at nationwide, which recaps the need to implement a monitoring system of forest cover at municipality level, state and national, aimed towards a future strategy to Reducing Emissions from Deforestation and Forest Degradation (REDD+).

It is also important to note the need in generating maps of land use and vegetation more accurate (scale 1:50,000) that allows to study this process with greater certainty and generate better estimates to raise local and regional strategies in the handling and optimal management of forest areas, such as reforestation programs and conservation. With this regard, it was noted that by using the maps of land use and vegetation at 1:250,000 from 


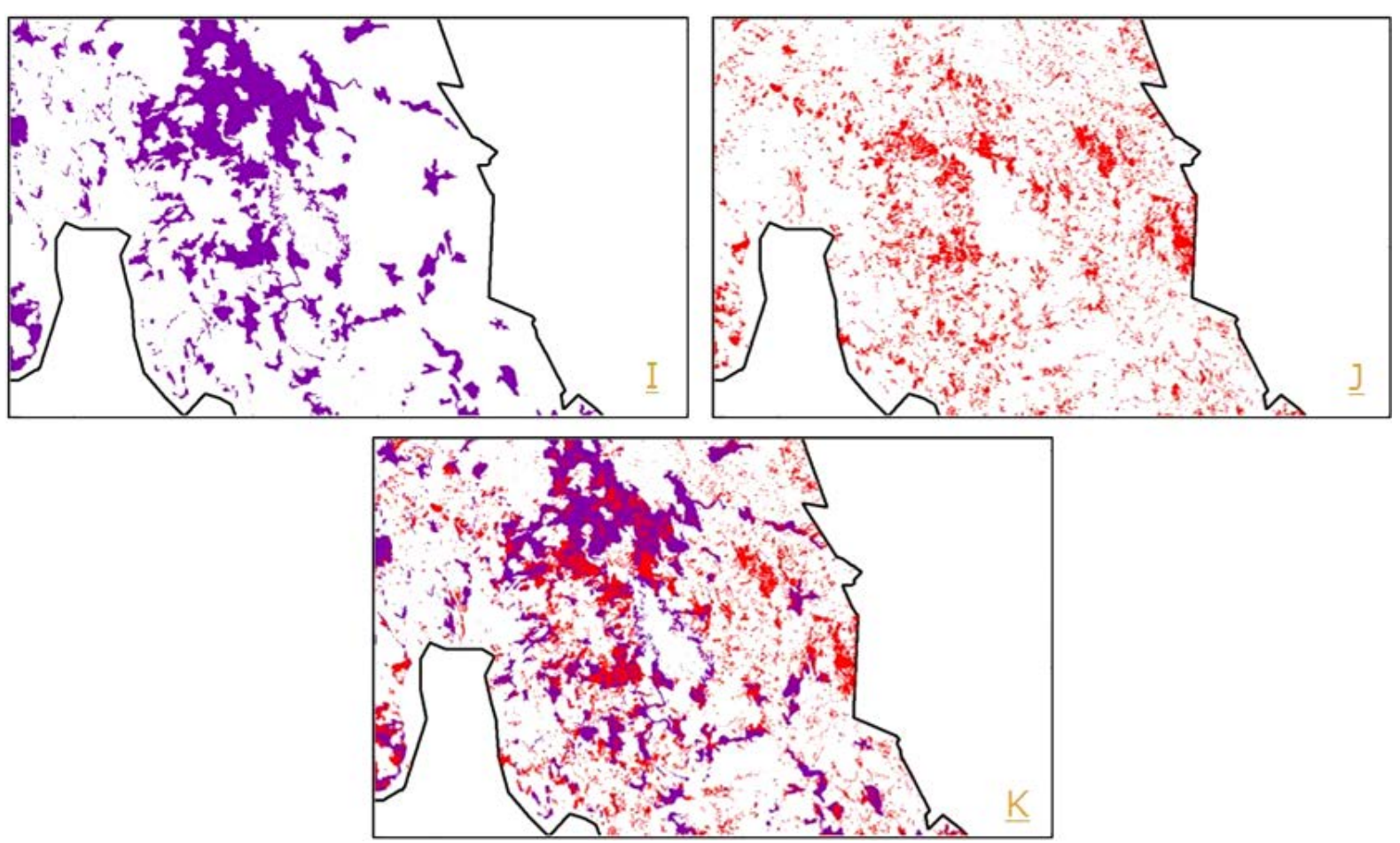

Figure 4. Deforestation by crossing maps of 1993 and 2011 at a 1:250,000 scale (I), deforestación using digital image processing of 1990-2014 (J), overlaying of deforestation I and J (K).

Table 4. Comparison of deforestation on the hot spot area 2.

\begin{tabular}{|c|c|c|c|c|c|}
\hline $\begin{array}{c}\text { Hot spot area } \\
2\end{array}$ & $\begin{array}{l}\text { Forest }\left(\mathrm{km}^{2}\right) \\
\text { Year }(0)\end{array}$ & $\begin{array}{c}\text { Forest }\left(\mathrm{km}^{2}\right) \\
\text { year }(1)\end{array}$ & $\begin{array}{l}\text { Deforestation } \\
\left(\mathrm{km}^{2}\right)\end{array}$ & $\begin{array}{l}\text { Deforestation } \\
\mathrm{Km}^{2} / \text { year }\end{array}$ & $\begin{array}{c}\text { Average annual } \\
\text { deforestation rate (\%) }\end{array}$ \\
\hline $\begin{array}{l}\text { By crossing maps of } 1993 \text { and } \\
2011 \text { at } 1: 250,000 \text { scale }\end{array}$ & $\begin{array}{l}8457.71 \mathrm{~km}^{2} \\
(\text { year 1993) }\end{array}$ & $\begin{array}{l}7374.31 \mathrm{~km}^{2} \\
(\text { year 2011) }\end{array}$ & $1296.40 \mathrm{~km}^{2}$ & $\begin{array}{c}57.0210 \\
\mathrm{Km}^{2} / \text { year }\end{array}$ & 0.71 \\
\hline $\begin{array}{l}\text { By digital image processing of } \\
\text { Landsat images } 1990-2014\end{array}$ & $\begin{array}{l}7898.05 \mathrm{~km}^{2} \\
(\text { year } 1990)\end{array}$ & $\begin{array}{c}6759.99 \mathrm{~km}^{2} \\
(\text { year } 2014)\end{array}$ & $1192.99 \mathrm{~km}^{2}$ & $\begin{array}{l}47.4190 \\
\mathrm{Km}^{2} / \text { year }\end{array}$ & 0.60 \\
\hline
\end{tabular}

INEGI, forest area and the average annual deforestation rate was overestimated. By using the official maps for the hot spot area number two were obtained approximately more than 500 hectares when INPE (2013) methodology was implemented, and a rate of 0.71 to 0.60 , respectively.

\section{References}

Achard, F., Mollicone, D., Stibig, H., Aksenov, D., Laestadius, L., Li, Z., \& Yaroshenko, A. (2006). Forest Ecology Management. Areas of Rapid Forest-Cover Change in Boreal Eurasia, 237, 322-334.

Arguelles, M., Benavides, C., \& Junguera, B. (2006). The Impact of Economic Activity in Asturias on Greenhouse Gas Emissions: Consequences for Environmental Policy within the Kyoto Protocol Framework. Journal of Environmental Management, 81, 249-264. http://dx.doi.org/10.1016/j.jenvman.2005.10.011

Bartalev, S., Kissiyar, O., Achard, F., Bartalev, S., \& Simonetti, D. (2014). Assessment of Forest Cover in Russia by Combining a Wall-to-Wall Coarse-Resolution Land-Cover Map with a Sample of $30 \mathrm{~m}$ Resolution Forest Maps. Journal of Remote Sensing, 35, 2671-2692. http://dx.doi.org/10.1080/01431161.2014.883099

Bins, S., Fonseca, L., Erthal, G., \& Li, M. (1993). Satellite Imagery Segmentation: A Region Growing Approach. Anais do VII Simpósio Brasileiro de Sensoriamento Remoto. Salvador, Brazil: INPE.

Câmara, G., Valeriano, D., \& Soares, J. (2006). Metodologia para o Cálculo da Taxa Anual de Desmatamento na Amazônia Legal. Brazil: Instituto Nacional de Pequisas Espaciais.

Céspedes, F., \& Moreno, S. (2010). Estimación del valor de la pérdida de recurso forestal y su relación con la reforestación 
en las entidades federativas de México. Investigación Ambiental, 2, 5-13.

Chuvieco, E. (2008). Teledetección Ambiental. Barcelona: Ariel.

Congalton, R., \& Green, K. (2009). Assesing the Accuracy of Remotely Sensed Data: Principles and Practices. London, New York: CRC Press.

Corrales, G. (2013). Análisis de cambio de uso de suelo en el estado de Sinaloa utilizando Sistemas de Información Geográfica. Tesis de Licenciatura, México: Universidad Autónoma de Sinaloa.

Denman, K., \& Guy, B. (2007). Couplings between Changes in the Climate System and Biogeochemistry. In S. Solomon, M. Qin, Z. Manning, M. Chen, K. Marquis, M. Averyt, \& H. Miller (Eds.), Climate Change 2007: The Physical Science Basis. Contribution of Working Group I to the Fourth Assessment Report of the Intergovernmental Panel on Climate Change (pp. 501-568). Cambridge: Cambridge University Press.

FAO (2010). Global Forest Resources Assessment 2010. Main Report, Rome: FAO.

FRA (2015). Global Forest Resources Assessment 2015. How Are the World's Forests Changing? Rome: Food and Agriculture Organization of the United Nation. http://www.fao.org/3/a-i4808e.pdf

FSI (2013). State of Forest Report 2009. Dehradun: Ministry of Environment and Forest, Government of India.

GOFC-GOLD (2013). A Sourcebook of Methods and Procedures for Monitoring and Reporting Anthropogenic Greenhouse Gas Emissions and Removals associated with Deforestation, Gains and Losses of Carbon Stocks in Forests Remaining Forests, and Forestation. The Netherlands: Wageningen University.

Hansen, M., Potapov, R., Moore, M., Hancher, S., Turubanova, A., Tyukavina, D., Townshend, J. et al. (2013). High-Resolution Global Maps of 21st-Century Forest Cover Change. Science, 342, 850-853.

http://dx.doi.org/10.1126/science.1244693

Houghton, R. (2012). Carbon Emissions and the Drivers of Deforestation and Forest Degradation in the Tropics. Current Opinion in Environmental Sustainability, 4, 597-603. http://dx.doi.org/10.1016/j.cosust.2012.06.006

INEGI (2013). Instituto Nacional de Estadistica y Geografia. http://www.inegi.org.mx/

INPE (2013). Monitoring of the Brazilian Amazonia. http://www.inpe.br/ingles/news/news.php?Cod Noticia=380

INPE-FUNCATE (2011). TerraAmazon 4.2. User's Guide Administrator. São José dos Campos: Instituto Nacional de Pesquisas Espaciais.

IPCC (2007). Climate Change 2007: The Physical Science Basis. In S. Solomon, D. Qin, M. Manning, Z. Chen, M. Marquis, K. B. Averyt, M. Tignor, \& H. L. Miller (Eds.), Contribution of Working Group I to the Fourth Assessment Report of the Intergovernmental Panel on Climate Change. Cambridge: Cambridge University Press.

Kanninen, M., Brockhaus, M., Murdiyarso, D., \& Nabuurs, G. (2010). Harnessing Forest for Climate Change Mitigation through REDD+. Austria: International Union of Forest Research Organizations (Iufro).

Landis, J., \& Koch, G. (1977). The Measurement of Observer Agreement for Categorical Data. Biometrics, 33, 159-174. http://dx.doi.org/10.2307/2529310

Mas, J. F. et al. (2004). Assessing Land Use/Cover Changes: A Nationwide Multidate Spatial Database for Mexico. International Journal of Applied Earth Observation and Geoinformation, 5, 249-261. http://www.sciencedirect.com/science/article/pii/S0303243404000339 http://dx.doi.org/10.1016/j.jag.2004.06.002

Naciones Unidas (1992). United Nations Framework Convention on Climate Change [Convenio marco de las Naciones Unidas sobre el Cambio Climático]. http://unfccc.int/resource/docs/convkp/conveng.pdf

Pacheco, C. (2014). Identification and Characterization of Deforestation Hot Spots in Venezuela using MODIS Satellite Images. Acta Amazónica, 44, 185-196. http://dx.doi.org/10.1590/S0044-59672014000200004

Pacheco, C., Aguado, I., \& Mollicone, D. (2011). Las causas de la deforestación en Venezuela: Un estudio retrospectivo. Biollania, 10, 281-292.

Pineda, N. (2010). Descripción, análisis y simulación de procesos forestales en el estado de México mediante Tecnologías de la Información Geográfica. Madrid: Universidad Alcalá de Henares.

Ramankutty, N., Graumlich, L., Achard, F., Alves , F., Chhabra, A., DeFries, R., Tumer, B. et al. (2006). Global Land-Cover Change: Recent Progress, Remaining Challenges. In E. Lambin, \& H. Geist (Eds.), Land-Use and Land-Cover Change (pp. 9-40). Berlín: Sprinnger.

Rudel, T., DeFries, R., Asner, G., \& Laurance, W. (2009). Changing Drivers of Deforestation and New Opportunities for Conservation. Conservation Biology, 23, 1396-1405. http://dx.doi.org/10.1111/j.1523-1739.2009.01332.x

Shimabukuro, Y., \& Smith, J. (1991). The Least-Squares Mixing Models to Generate Fraction Images derived from Remote Sensing Multispectral Data. Geoscience and Remote Sensing, 29, 16-20. http://dx.doi.org/10.1109/36.103288

Skutscha, M., Mas, J. F., Bocco, G., Bee, B., Cuevas, G., \& Gao, Y. (2013). Deforestation and Land Tenure in Mexico: A 
Response to Bonilla-Moheno et al. Land Use Policy, 39, 390-396. http://dx.doi.org/10.1016/j.landusepol.2013.11.013

Torres, J. M. (2008). Determinantes del cambio de uso/cobertura arbolada en México: un enfoque a través de probabilidades de transición. CIDE Documento de Trabajo 450, CIDE.

USGS (2016). US Geological Survey. http://glovis.usgs.gov/

Velázquez, A. (2008). La dinámica de la cubierta forestal de México [Forested Land Cover Dynamics of Mexico]. México. https://www.researchgate.net/profile/Alejandro Velazquez/publication/263254418 La dinmica de la cubierta forestal de Mxico/links/54e3720d0cf2dbf60692b52c.pdf

Viola, F., Paiva, S., \& Savi, M. (2010). Analysis of the Global Warming Dynamics from Temperature Time Series. Ecological Modelling, 221, 1964-1978. http://dx.doi.org/10.1016/j.ecolmodel.2010.05.001

\section{Submit or recommend next manuscript to SCIRP and we will provide best service for you:}

Accepting pre-submission inquiries through Email, Facebook, Linkedin, Twitter, etc A wide selection of journals (inclusive of 9 subjects, more than 200 journals)

Providing a 24-hour high-quality service

User-friendly online submission system

Fair and swift peer-review system

Efficient typesetting and proofreading procedure

Display of the result of downloads and visits, as well as the number of cited articles

Maximum dissemination of your research work

Submit your manuscript at: http://papersubmission.scirp.org/ 